\title{
Kajian Geoteknik untuk Perencanaan Pembangunan Pemukiman Baru pada Kawasan Handil Berkat Makmur, Kabupaten Kapuas, Kalimantan Tengah
}

\author{
Fauziah $\mathrm{Ali}^{1 *}$, Najib ${ }^{1}$, Rinal Khaidar $\mathrm{Ali}^{1}$ \\ ${ }^{1}$ Departemen Teknik Geologi, Universitas Diponegoro, Semarang
}

\begin{abstract}
Abstrak
Pengembangan dan pembangunan di Kawasan Handil Berkat Makmur, Kabupaten Kapuas, Kalimantan Tengah semakin pesat, terutama seiring dengan pertumbuhan penduduk yang semakin meningkat. Salah satu langkah yang perlu diambil untuk mengurangi nilai risiko dalam mengembangkan lahan adalah dengan melakukan kajian geoteknik. Penelitian ini bertujuan untuk mengetahui jenis, sifat fisik, dan sifat mekanika tanah, menentukan pondasi yang sesuai dengan kondisi tanah, dan memberikan rekomendasi rekayasa teknik untuk menambah daya dukung tanah pada lokasi penelitian.

Metode yang digunakan dalam penelitian meliputi pengambilan sampel, disturbed dan undisturbed, menggunakan bor tangan, pemetaan geoteknik, dan uji sondir. Sampel bor disiapkan untuk uji sifat fisik tanah.

Jenis tanah pada lokasi penelitian adalah endapan gambut, lempung, dan lanau berlempung, yang bersifat jenuh, ekspansif, konsistensi sangat lunak - keras, dan kondisi air tidak dapat mengalir keluar rongga pori. Nilai qu berdasarkan data sondir pada kedalaman $1-6 \mathrm{~m}$, sebesar $56,80-66,32 \mathrm{ton} / \mathrm{m}^{2}$, dan qa sebesar $18,93-22,11$ ton $/ \mathrm{m} 2$, sedangkan nilai qu berdasarkan data laboratorium sebesar $0,65-2,48$ ton $/ \mathrm{m}^{2}$, dan qa sebesar $0,22-0,83$ ton $/ \mathrm{m}^{2}$. Rekomendasi rekayasa teknik untuk menambah daya dukung tanah, dapat menggunakan pondasi cerucuk untuk pondasi rumah, dan penggunaan geotekstil serta penambahan tanah urugan pada jalan yang berada di lingkungan pemukiman.
\end{abstract}

Kata kunci: geoteknik, daya dukung tanah, Kabupaten Kapuas.

\begin{abstract}
The area development of Handil Berkat Makmur, Kapuas District, Central Kalimantan is increasing rapidly, especially considering the increasing population growth. One of the steps that needs to be taken to reduce the risk in developing the area is to conduct geotechnical studies. This study aims to determine the type, physical properties, and mechanical properties of the soil, determine the appropriate foundation based on the soil conditions, and provide engineering recommendations to increase the soil bearing capacity within the study area.

The methods applied in the study are including sampling, disturbed and undisturbed, using hand drill, geotechnical mapping, and sondir test. Bore samples were prepared for soil physical properties test. The soil types at the study sites were peat deposits, clay, and silt clay, which is saturated, expansive, very soft - hard consistency, and no water outflow from the pores. The value of qu based on sondir data at depth of 1 - $6 \mathrm{~m}$, equal to 56,80 - 66,32 ton/ $\mathrm{m}^{2}$, and qa equal to $18,93-22,11 \mathrm{ton} / \mathrm{m}^{2}$, while value of qu based on laboratory data equal to $0,65-2,48 \mathrm{ton} / \mathrm{m}^{2}$, and qa equal to $0,22-0,83 \mathrm{ton} / \mathrm{m}^{2}$. Technical engineering recommended to increase the carrying capacity of the soil, is to use cerucuk foundation for the foundation of the house, and the use of geotextiles and the addition of urugan land on the road residing in the neighborhood.
\end{abstract}

Keyword: geotechnical, soil bearing capacity, Kapuas District.

\section{PENDAHULUAN}

Pengembangan dan pembangunan di Kawasan Handil Berkat Makmur, Kabupaten Kapuas, Kalimantan Tengah semakin pesat, terutama seiring dengan pertumbuhan penduduk yang semakin meningkat. Kegagalan dalam suatu pembangunan dapat terjadi akibat eksploitasi tanah yang melebihi daya dukung tanah secara umum (Virman, 2013). Salah satu langkah yang perlu diambil untuk mengurangi nilai risiko kegagalan dalam mengembangkan lahan adalah dengan melakukan kajian geoteknik. 
Penelitian ini bertujuan untuk mengetahui jenis, sifat fisik, dan sifat mekanika tanah, menentukan pondasi yang sesuai dengan kondisi tanah, dan memberikan rekomendasi rekayasa teknik untuk menambah daya dukung tanah pada lokasi penelitian.

Kemiringan lereng di daerah penelitian berkisar antara $1^{\circ}-2^{\circ}$ dengan sebagian besar wilayah masih dipengaruhi pasang surut sungai sehingga sering dijumpai setempat genangangenangan air, bahkan endapan gambut terdistribusi luas (Bappeda Kabupaten Kapuas, 2013). Berdasarkan Peta Geologi Regional Lembar Banjarmasin (Sikumbang dan Heryanto, 1994) dan Lembar Amuntai (Heryanto dan Sanyoto, 1994), lokasi penelitian tertutup oleh endapan aluvium yang terdiri dari kerikil, pasir, lanau, lempung, lumpur, dan gambut. Endapan gambut terbentuk secara insitu di dalam lensa-lensa tipis yang berundulasi dan di antara tanggul-tanggul sungai membentuk rawa. Lokasi penelitian sendiri sebagian besar digunakan untuk perkebunan $(68 \%)$, selebihnya pemukiman $(10 \%)$, ladang (2\%), dan kawasan semak belukar (20\%) (Gambar 1).

\section{Deskripsi Lapangan Tanah Organik Berbutir Halus}

Jenis tanah dapat disebut sebagai tanah organik berbutir halus jika dijumpai partikel organik dalam properti tanah. Kenampakan yang dipakai untuk mendeskripsi tanah, yaitu: warna (bukan bagian spesifik dari teknik tetapi dapat dijadikan sebagai indikator dari proses yang telah dan sedang berlangsung), konsistensi dan kepadatan relatif (plastis dan nonplastis, sangat lunak hingga keras, sangat lepas hingga sangat padat), ukuran butir (halus, pasir, kerikil), bentuk butir (pada butir kasar dapat berbentuk menyudut, agak menyudut, membundar), kelembaban (kering, lembab, basah), dan reaksi HCL (tidak bereaksi, bereaksi lemah, bereaksi kuat).

\section{Daya Dukung Tanah}

Wesley (2010) menyebutkan bahwa daya dukung tanah adalah istilah yang menyatakan kemampuan tanah menahan beban pada permukaan tanah maupun menahan beban pada kedalaman di bawah permukaan seperti halnya dengan fondasi. Perhitungan daya dukung tanah dapat digunakan untuk menjamin kemantapan fondasi, yang bergantung pada kekuatan geser tanah dan daya duukungnya, serta untuk menjamin bahwa penurunan fondasi tidak melebihi batas yang diperbolehkan. Fahriani dan Apriyanti (2015) menyebutkan bahwa estimasi daya dukung tiang tunggal dengan beban vertikal ditentukan berdasarkan data sondir dan sifat fisik tanah.

Tanah lempung memiliki sifat kohesif dan me-

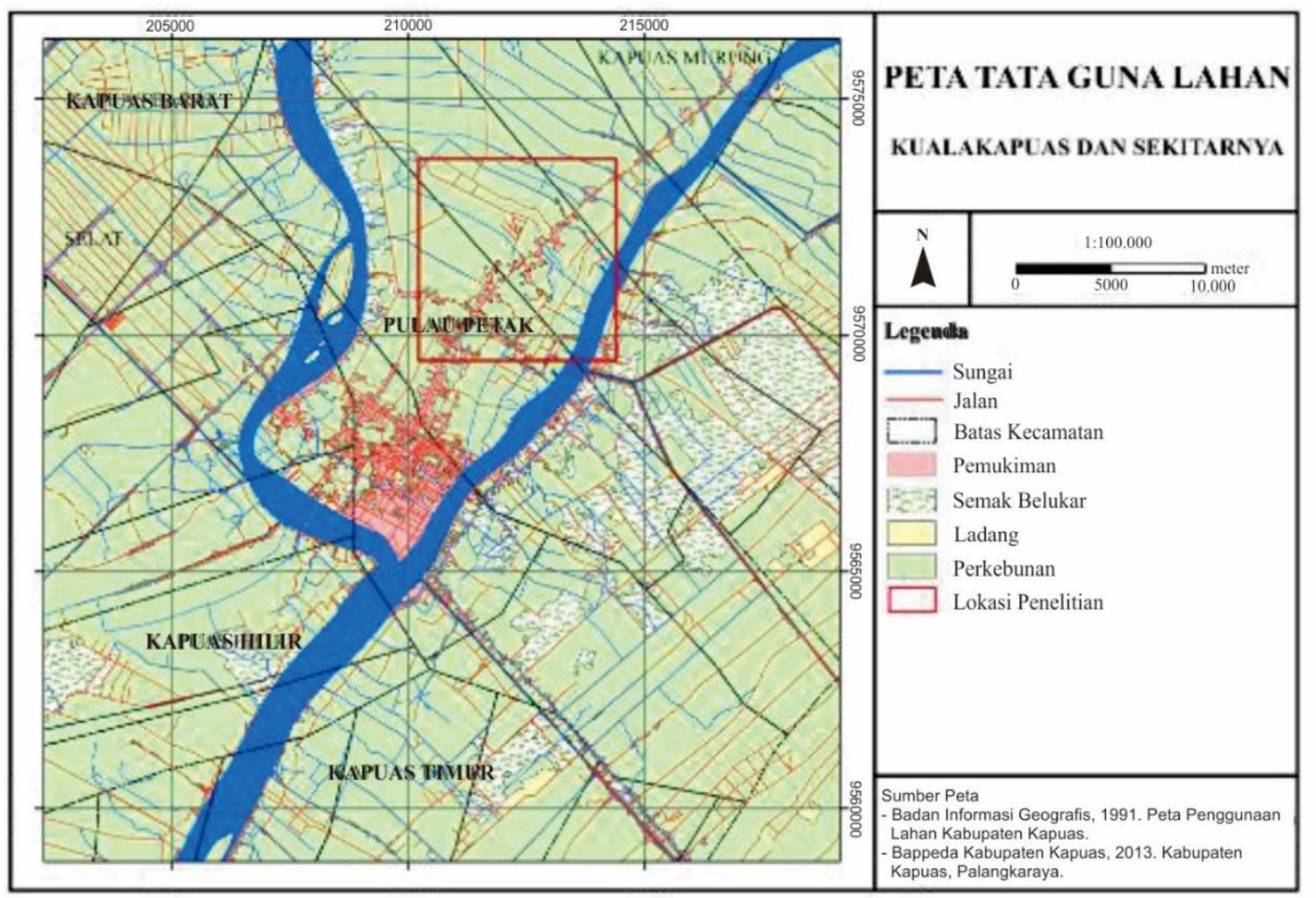

Gambar 1. Peta tata guna lahan di daerah penelitian dan sekitarnya. 
miliki karakteristik sebagai berikut : a) kuat geser rendah, semakin rendah bila kadar air bertambah, b) cenderung kembang susut (ekspansif), c) sangat dipengaruhi oleh kadar air dan plastisitas tinggi, d) fraksi butir halus yang sangat mempengaruhi kualitas, dan e) memerlukan stabilisasi dan pemadatan, tidak baik dijadikan sebagai tanah urugan.

\section{METODOLOGI}

Penelitian ditempuh melalui beberapa tahapan setelah dilakukan studi pustaka terlebih dulu. Tahapan pertama meliputi pengambilan data primer di lapangan menggunakan bor tangan dan sondir pada titik-titik yang dapat merepresentasikan daerah penelitian. Selanjutnya, undisturbed sample yang diperoleh diuji di laboratorium untuk dapat mengetahui sifat-sifat fisik tanah. Hasil pengujian laboratorium tersebut diolah untuk pembuatan peta geoteknik serta menjawab tujuan penelitian.

\section{Pengeboran tangan}

Pengeboran dilakukan pada 2 titik HB-1 dan HB-2 (Gambar 2) hingga kedalaman $4 \mathrm{~m}$. Undisturbed sampel diambil dari interval 3,5 m - $4 \mathrm{~m}$ yang selanjutnya diterapkan beberapa pengujian di laboratorium.

\section{Sondir}

Pada 5 titik (S-1, S-2, S-3, S-4, S-5) di lokasi penelitian (Gambar 2) dilakukan uji sondir hingga kedalaman $25 \mathrm{~m}$ dengan alat sondir lokal berkapasitas 2,5 ton yang dilengkapi rod berdiameter $3 / 4$ inchi. Uji dioperasikan hingga sondir mencapai nilai perlawanan konus qc $>$ $150 \mathrm{~kg} / \mathrm{cm} 2$ atau kedalaman $25 \mathrm{~m}$.

Uji sondir bertujuan untuk mengetahui perlawanan atau penetrasi konus (qc) dan hambatan lekat (LF) (Paulus, 1997 dalam Utami dan Hermawan, 2003). Rasio friksi (FR) tanah ditentukan berdasarkan rentang nilai penetrasi konus yang ditetapkan oleh Terzaghi dan Peck (1948). Selanjutnya klasifikasi tanah dilakukan dengan cara mengeplot nilai qc dan FR pada diagram Robertson dkk. (1986) yang ditunjukkan di Gambar 3.

\section{Uji Laboratorium}

Uji dilakukan terhadap sampel bor tangan dari titik bor HB-1 dan HB-2. Pengujian dilakukan di Laboratorium Mekanika Tanah serta Laboratorium Ekologi dan Produksi Tanaman, Universitas Diponegoro, dan Laboratorium Mekanika Tanah, Universitas Lambung Mangkurat.

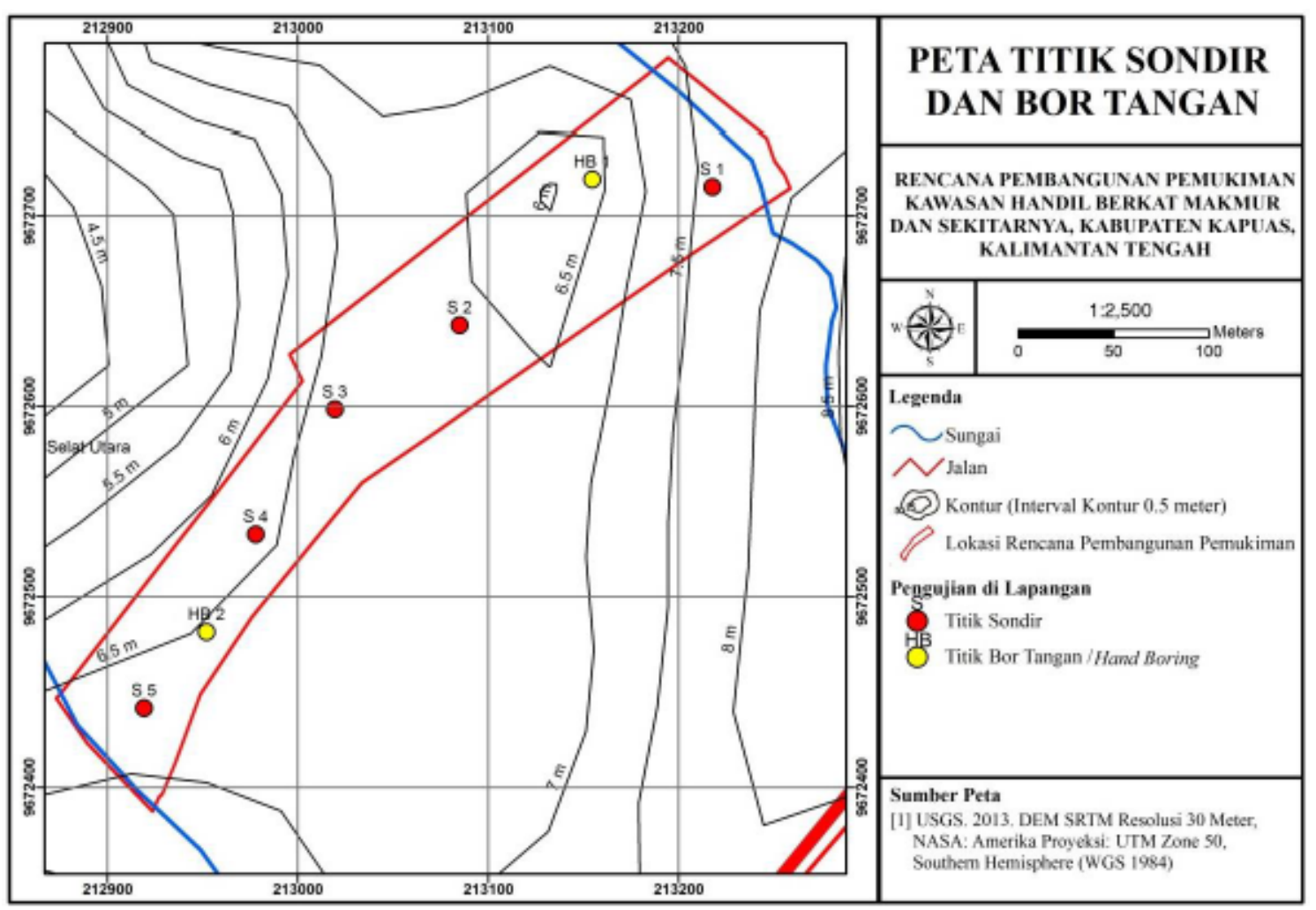

Gambar 2. Lokasi titik sondir dan sumur bor tangan. 


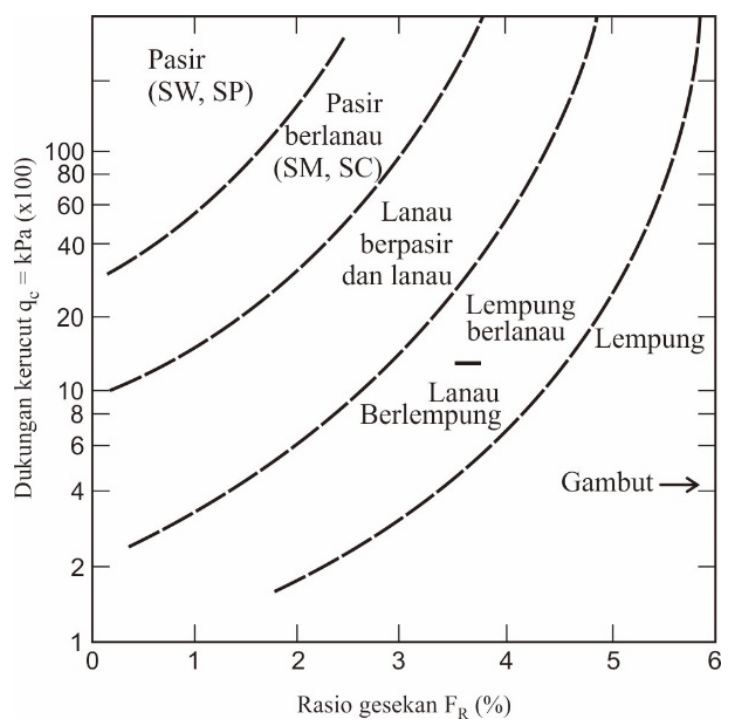

Gambar 3. Klasifikasi tanah berdasarkan nilai penetrasi konus dan rasio gesekan (Robertson, 1986).

Pengujian yang dilakukan adalah :

1. Uji fisik tanah meliputi pengukuran water content, volumetric weight (berat isi sampel tanah) yang merupakan perbandingan antara berat total dan volume total, dan specific gravity (berat jenis sampel tanah) yang diperoleh dari perbandingan berat isi partikel padat dengan berat isi air.

2. Uji atterberg limit dilakukan untuk mengetahui batas cair, batas plastis, dan indeks plastisitas sampel tanah.

3. Uji hydrometer diperlukan untuk memperoleh nilai persentase tanah berbutir halus pada sampel.

4. Uji permeabilitas merupakan uji untuk mengetahui koefisien permeabilitas sampel tanah.

5. Unconfined Compression Strength Test dilakukan untuk dapat menentukan nilai kuat tekan sampel tanah.

6. Consolidation test dan direct shear test masing-masing dilakukan untuk mengetahui koefisien konsolidasi dan kohesi serta sudut geser tanah.

\section{Estimasi Daya Dukung Tanah}

Nilai qc dari hasil sondir digunakan untuk mengestimasi daya dukung tanah. Penelitian ini mengaplikasikan rumus perhitungan daya dukung tanah (qult) Bowles (Chairullah, 2013) dalam kasus pemakaian pondasi segiempat pada jenis tanah lempung yang bersifat kohesif, yaitu:

$$
\mathrm{q}_{\text {ult }}=5+0,34 \mathrm{q}_{\mathrm{c}}\left(\mathrm{kg} / \mathrm{cm}^{2}\right)
$$

dan estimasi daya dukung izin tanah (qa) menggunakan persamaan Meryerhoff (Sugiyanto, 2003), yaitu :

$$
q_{a}=\frac{q_{u l t}}{3}
$$

Akan tetapi, nilai daya dukung tanah yang diestimasi berdasarkan hasil uji sondir sangat dipengaruhi oleh penetrasi konus. Lain halnya dengan estimasi daya dukung tanah yang diperoleh dari data hasil uji laboratorium mempertimbangkan berbagai parameter, yaitu : nilai kohesi, berat isi tanah, kedalaman tanah yang ditinjau, dan lebar fondasi. Dengan demikian, diharapkan nilai daya dukung tanah lebih merepresentasikan kondisi sebenarnya di lapangan. Estimasi daya dukung tanah berdasarkan data uji laboratorium dilakukan dengan menggunakan persamaan dari Panduan Departemen Pekerjaan Umum Tahun 2005, yaitu :

$$
\mathrm{Qu}=\mathrm{cN}_{\mathrm{c}}+\gamma \mathrm{DN}_{\mathrm{q}}+0,5 \mathrm{BN}_{\gamma}
$$

keterangan : $\mathrm{Qu}=$ daya dukung tanah $(\mathrm{kPa}) ; \mathrm{C}$ $=$ kohesi $(\mathrm{kPa}) ; \gamma=$ berat isi tana $\left(\mathrm{kN} / \mathrm{m}^{3}\right) ; \mathrm{D}=$ kedalaman tanah yang ditinjau (m); $\mathrm{B}=$ lebar fondasi atau timbunan (m); $\mathrm{N}_{\mathrm{c}}, \mathrm{N}_{\mathrm{q}}, \mathrm{N}_{\gamma}=$ faktor daya dukung.

\section{HASIL}

Observasi lapangan menunjukkan bahwa lokasi penelitian didominasi oleh tanah berwarna coklat kehitaman, berukuran butir lempung $(<1 / 256 \mathrm{~mm})$ hingga lanau $(1 / 256-1 / 16 \mathrm{~mm})$. Tanah memiliki konsistensi lunak - sangat lunak, persentase butir halus $>70 \%$ dan banyak ditemukan akar tanaman, sehingga dapat disebut sebagai tanah organik (gambut). Kelembaban tanah tersebut berkisar antara lembab hingga basah yang ditandai dengan adanya tanah yang basah dan air yang bebas terlihat.

\section{Uji Sondir}

Pada titik S-1, S-2, dan S-3, uji dihentikan ketika mencapai kedalaman $25 \mathrm{~m}$ walaupun nilai qc belum menembus $150 \mathrm{~kg} / \mathrm{cm}^{2}$. Nilai qc telah mencapai $150 \mathrm{~kg} / \mathrm{cm} 2$ pada kedalaman 24 $m$ di titik S-4 dan S-5. Hasil uji sondir yang diplot pada diagram rasio gesekan dan qc (Gambar 5) sebagian besar berada pada area lempung berlanau-lanau berlempung dan lempung. Hanya dua nilai, masing-masing berasal dari S- 4 dan S-5, yang berada pada area lanau berpasir dan lanau. Estimasi daya dukung tanah juga dilakukan dan hasilnya ditampilkan pada Tabel 2 dan 3). 


\section{Pengambilan Sampel Bor Tangan}

Sampel HB-1 memiliki topsoil dengan ketebalan 0,2 m, selanjutnya kedalaman 0,2 0,8 m merupakan interval lempung berwarna abu-abu kecoklatan dengan konsistensi lunak, pada kedalaman 1,0 - 3,4 m teramati lempung berwarna abu-abu kehitaman konsistensi lunak. Selanjutnya undisturbed sampel diambil dari kedalaman 3,5 - 4,0 m (Gambar 4).

Muka airtanah berada pada kedalaman $0,8 \mathrm{~m}$.

Pada titik HB-2 dijumpai topsoil setebal 0,2 $\mathrm{cm}$, selanjutnya di kedalaman $0,2-0,6 \mathrm{~m}$ tersusun dari lempung berwarna abu-abu kecoklatan sangat lunak, dan pada interval $0,8-$ 3,4 terdiri dari lempung berwarna abu-abu kehitaman dan lunak. Undisturbed sample diambil dari kedalaman 3,5-4,0 m. Air mulai keluar pada kedalaman $0,6 \mathrm{~m}$ yang sekaligus menjadi indikator muka airtanah.

\section{Sifat Fisik Tanah}

Sampel HB-1 (Gambar 4) memiliki kadar air rata-rata sebanyak $76,07 \%$, sedangkan pada sampel tanah HB-2 memiliki kadar air rata-rata sebanyak 91,86\%. Hasil uji atterberg limit dari sampel tanah HB-1 menunjukkan nilai batas cair 66,60, batas plastis 33,33, dan nilai indeks plastisitas 33,27. Sampel tanah HB-2 memiliki nilai batas cair 69,70 , batas plastis 34,64 , dan indeks plastisitas 35,06 . Nilai berat isi sampel tanah memiliki nilai 1,47-1,62.

\section{Uji Permeabilitas}

Sampel tanah HB-1 memiliki koefisien permeabilitas $1.077 \times 10^{-8} \mathrm{~m} /$ detik sedangkan pada sampel HB-2 memiliki koefisien permeabilitas $1.620 \times 10^{-8} \mathrm{~m} /$ detik.

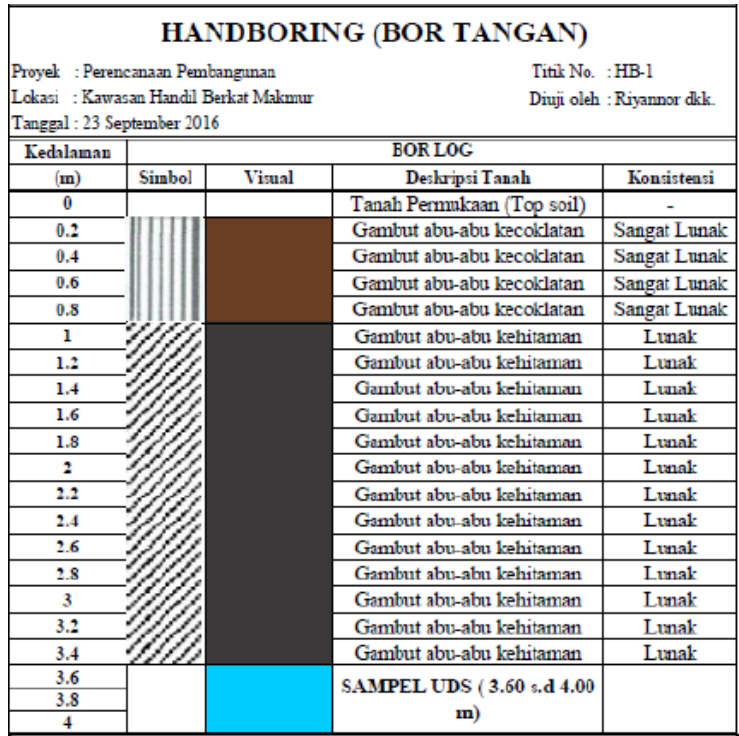

Catatan

Muka air dari kedalıman 0,8 meter

Gambar 4. Kolom tanah dan deskripsi sumur HB-1.

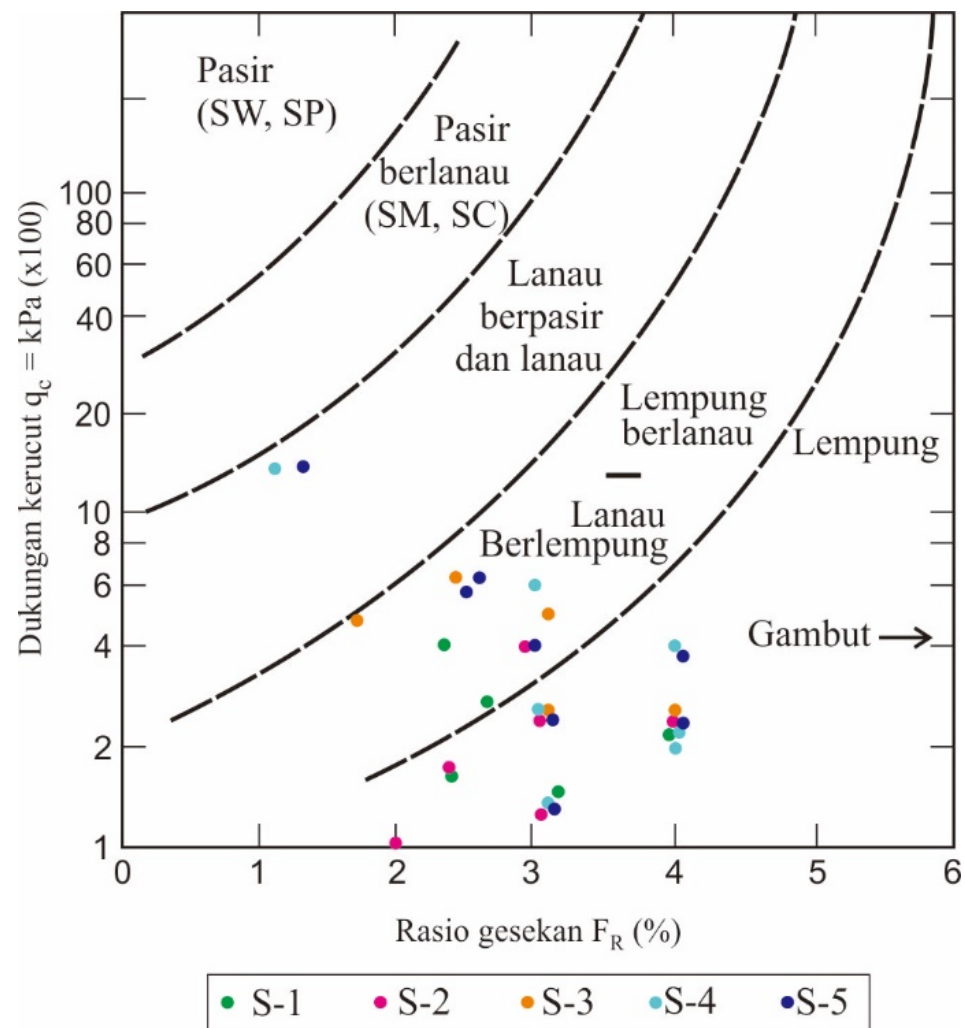

Gambar 5. Nilai penetrasi konus terhadap rasio gesekan hasil uji sondir di lokasi penelitian. 
Tabel 1. Hasil Pengujian Berat Jenis Sampel HB-1

\begin{tabular}{lccc}
\hline \multicolumn{1}{c}{ Kondisi sampel } & \multicolumn{3}{c}{ Nomor Piknometer } \\
\cline { 2 - 4 } & 3 & 5 & 7 \\
\hline Berat Piknometer kosong $(\mathrm{m} 1)(\mathrm{gr})$ & 27,10 & 27,23 & 28,12 \\
Berat Piknometer kosong + sampel tanah $(\mathrm{m} 2)(\mathrm{gr})$ & 36,60 & 36,73 & 37,62 \\
Berat Piknometer kosong + sampel tanah + air hingga penuh $(\mathrm{m} 3)(\mathrm{gr})$ & 82,98 & 83,12 & 87,62 \\
Berat Piknometer + air $(\mathrm{m} 4)(\mathrm{gr})$ & 7,11 & 77,23 & 78,12 \\
Berat jenis $G_{S}=\frac{\left(m_{2}-m_{1}\right)}{\left(m_{4}-m_{1}\right)-\left(m_{3}-m_{2}\right)}$ & 2,62 & 2,63 & 2,61 \\
Rata-rata berat jenis & & 2,62 & \\
\hline
\end{tabular}

Tabel 2. Hasil estimasi nilai daya dukung tanah berdasarkan data uji sondir

\begin{tabular}{ccc}
\hline Kedalaman (m) & qult (ton $\left./ \mathbf{m}^{\mathbf{2}}\right)$ & qa (ton $\left./ \mathbf{m}^{\mathbf{2}}\right)$ \\
\hline 1 & 56,80 & 18,93 \\
3 & 60,20 & 20,07 \\
6 & 66,32 & 22,11 \\
\hline
\end{tabular}

Tabel 3. Hasil estimasi nilai daya dukung tanah berdasarkan data uji laboratorium

\begin{tabular}{ccc}
\hline Kedalaman (m) & quit $\left(\mathbf{t o n} / \mathbf{m}^{\mathbf{2}}\right)$ & qa $\left(\mathbf{t o n} / \mathbf{m}^{\mathbf{2}}\right)$ \\
\hline 1 & 0,65 & 0,22 \\
3 & 1,32 & 0,44 \\
6 & 2,48 & 0,83 \\
\hline
\end{tabular}

Uji Unconfined Compression Strength (UCS)

Pada saat uji UCS, sampel undisturbed dari HB1 retak pada tegangan $0,257 \mathrm{~kg} / \mathrm{cm}^{2}$ atau sama dengan 25,2 $\mathrm{MPa}$ dan memiliki nilai regangan sebesar 16,7\%. Sampel undisturbed HB-2 retak pada uji UCS dengan tekanan $0,205 \mathrm{~kg} / \mathrm{cm}^{2}$ $(=20,1 \mathrm{MPa})$ dan memiliki nilai regangan sebesar $23,1 \%$. Kedua sampel tersebut memiliki skala kekuatan lemah (Deere, 1990 dalam Verhoef, 1994).

\section{Uji Konsolidasi dan Direct Shear}

Hasil uji konsolidasi menyebutkan bahwa sampel HB-2 memiliki nilai koefisien konsolidasi (Cv) sebesar $0,02 \mathrm{~cm}^{2} /$ detik dengan indeks kompresi $(\mathrm{Cc})$ sebesar 0,61 - 0,82 dan dikategorikan sebagai lempung lunak. Uji direct shear terhadap sampel undisturbed bor tangan menghasilkan nilai kohesi $0,09-0,1 \mathrm{~kg} / \mathrm{cm}^{2}$, nilai sudut geser dalam sebesar $10,04^{\circ}-11,58^{\circ}$, dan nilai kuat geser 12,00 $\mathrm{kPa}$.

\section{Estimasi Daya Dukung Tanah}

Estimasi menggunakan data hasil uji sondir (Tabel 2) dan hasil uji laboratorium (Tabel 3) membuktikan bahwa tanah di lokasi penelitian memiliki daya dukung tanah yang sangat rendah karena memiliki nilai rata-rata qult dan qa di bawah ambang batas tanah dengan daya dukung kuat, masing-masing 440 ton $/ \mathrm{m}^{2}$ dan $146,67 \mathrm{ton} / \mathrm{m}^{2}$.

\section{PEMBAHASAN}

\section{Kondisi Geoteknik Lokasi Penelitian}

Berdasarkan hasil observasi lapangan, tanah di lokasi penelitian memiliki jenis tanah gambut berlempung kelanauan dengan konsistensi lunak - sangat lunak, dan kelembaban lembab basah. Nilai kadar air yang diperoleh dari uji laboratorium menunjukan bahwa tanah di lokasi penelitian memiliki sifat jenuh air (Das, 2000). Hal tersebut juga dipengaruhi oleh adanya pasang surut sungai yang berada pada lokasi penelitian.

Nilai berat jenis tanah $(2,6-2,9)$ dari hasil uji laboratorium selaras dengan hasil observasi lapangan yang menentukan bahwa lokasi penelitian terusun dari tanah berlempung atau berlanau. Nilai plastisitas pada sampel tanah yang telah diuji memiliki nilai $>17$, hal tersebut menunjukkan bahwa tanah yang terdapat pada lokasi penelitian merupakan lempung yang kohesif. Semakin tinggi nilai indeks plastisitas maka akan semakin bersifat expansive, artinya sangat mudah terpengaruh kadar air. Dengan demikian, tanah akan sangat mengembang jika kadar air tinggi (jenuh air) dan akan sangat menyusut jika kadar air rendah (kering) (Wesley, 2010).

Koefisien permeabilitas merepresentasikan bahwa kondisi air pada daerah penelitian secara umum tidak dapat mengalir keluar dari rongga karena gravitasi, sehingga hampir tidak dapat dirembesi oleh air.

Integrasi dari data lapangan dan hasil analisis laboratorium menghasilkan peta geoteknik lokasi penelitian. Peta menunjukkan bahwa endapan gambut lempung lanauan terdistribusi di seluruh permukaan lokasi penelitian (Gambar 6). Penampang sayatan geologi yang direkonstruksi dari data sumur menunjukkan endapan gambut semakin tebal relatif ke timurlaut (Gambar 6). 


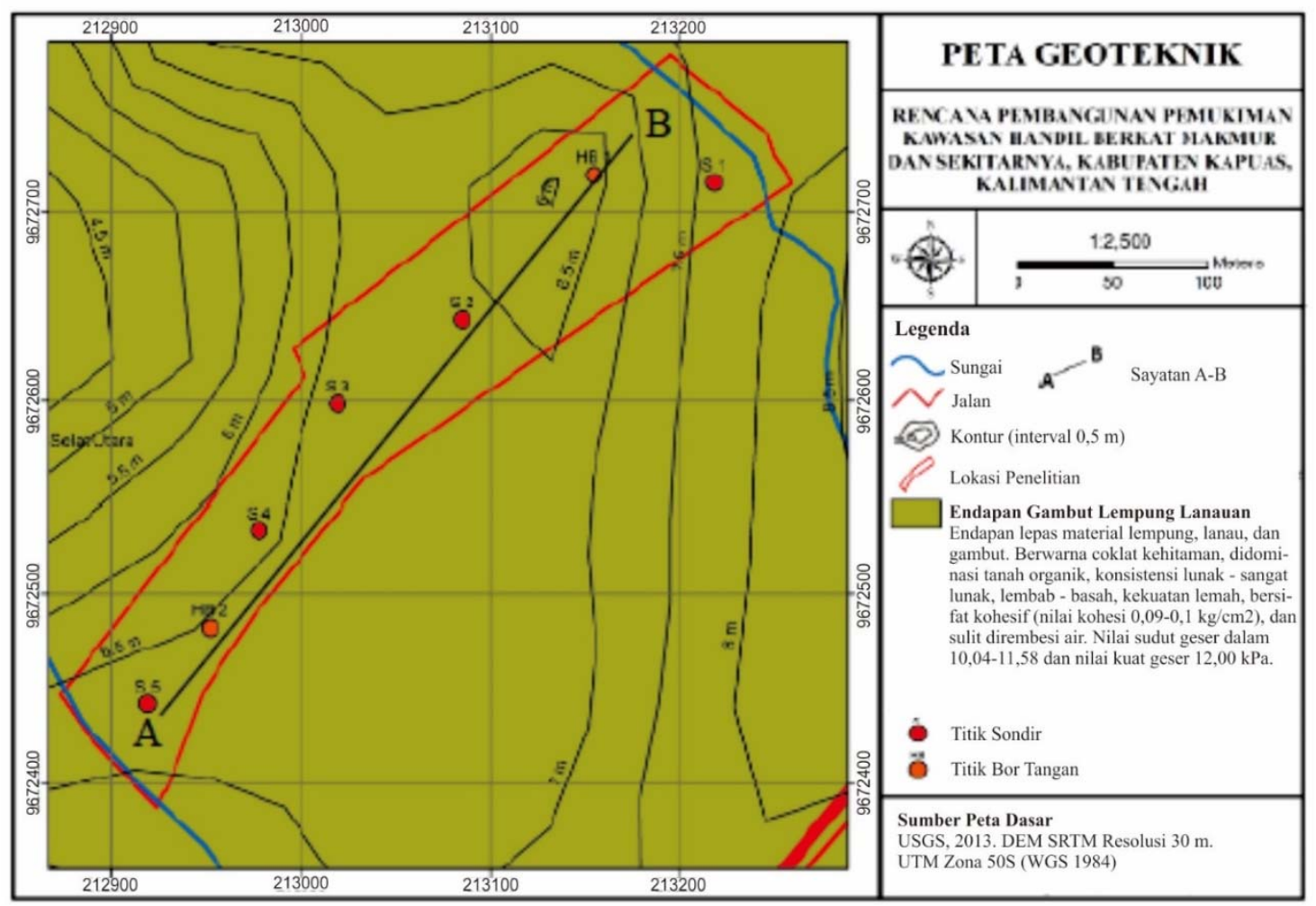

PENAMPANG A-B

SKALA HORIZONTAL $1: 2500$

SKALA VERTIKAL $1: 1000$
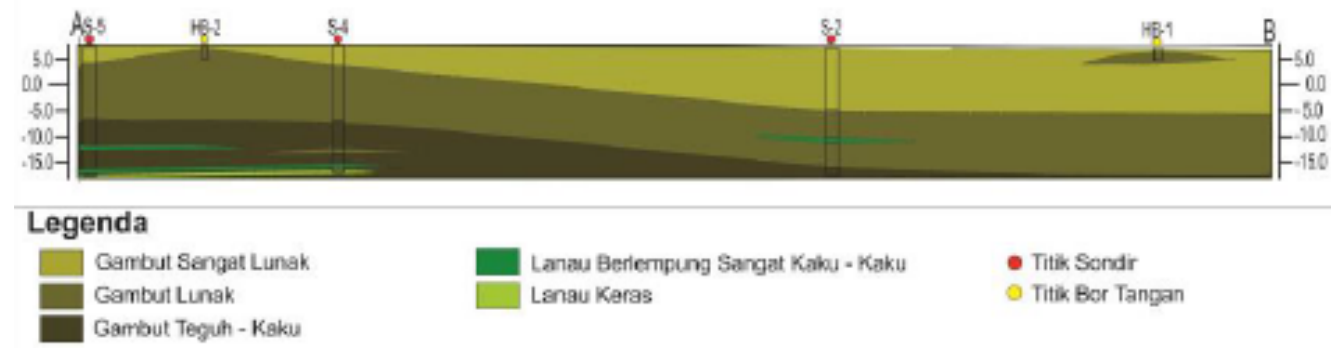

Lanau Beriempung Sangat Kaku - Kaku - Titik Sondr

Lenau Keras

- Titik Bor Tangan

Gambar 6. Peta Geoteknik lokasi penelitian dan penampang sayatan A-B.

\section{Rekomendasi Pondasi}

Hasil analisis dalam penelitian ini dijadikan landasan untuk mengeluarkan rekomendasi pondasi yang dapat dipasang di lokasi penelitian. Penentuan pondasi sendiri dilakukan dengan mempertimbangkan lapisan keras. Pada lokasi penelitian, lapisan keras ditandai dengan nilai penetrasi konus $>150$ $\mathrm{kg} / \mathrm{cm}^{2}$ hanya dijumpai pada titik S-4 dan S-5 di kedalaman $>5 \mathrm{~m}$.

Berdasarkan kondisi tersebut, maka disarankan untuk menggunakan pondasi dangkal, yaitu pondasi yang dasarnya dekat dengan permukaan tanah. Jenis pondasi dangkal yang umum digunakan untuk rumah dan bangunan sederhana adalah pondasi segiempat, sedangkan untuk bangunan penahan air dapat menggunakan pondasi lajur biasa. Di antara kedua pondasi tersebut, pondasi segiempat memiliki nilai kekuatan lebih besar jika dibandingkan pondasi lajur.

Asumsi pembebanan (beban mati, hidup, dan balok) rumah 1 lantai seluas $36 \mathrm{~m}^{2}$ dibuat sebesar $15.573 \mathrm{~kg}$ (15,57 ton) dengan rincian sebagai berikut:

Dinding $1 / 2$ batu $250 \mathrm{~kg}$

Beton polos $\quad 2.100 \mathrm{~kg}$

Partisi dinding $50 \mathrm{~kg}$

Air $\quad 1.000 \mathrm{~kg}$

Baja $\quad 7.750 \mathrm{~kg}$

Beton $\quad 2.400 \mathrm{~kg}$

Lantai $\quad 250 \mathrm{~kg}$

Manusia $\quad 200 \mathrm{~kg}$

Air Hujan $\quad 20 \mathrm{~kg}$

Toilet $\quad 250 \mathrm{~kg}$

Atap $\quad 250 \mathrm{~kg}$

Sloof $\quad 90 \mathrm{~kg}$

Balok atap $\quad 875 \mathrm{~kg}$

Balok dinding $\quad 88 \mathrm{~kg}$ 
Tanah seluas $36 \mathrm{~m}^{2}$ pada kedalaman $3 \mathrm{~m}$ di lokasi penelitian dapat memberikan daya dukung untuk beban sebesar 15,84 ton (qa = 0,44 ton $/ \mathrm{m}^{2}$ ). Rekayasa teknik yang dapat dilakukan adalah menambahkan pondasi segiempat dengan cerucuk sebagai tambahan (Gambar 7). Cerucuk sendiri sangat disarankan untuk jenis tanah lunak karena mampu memperlambat kecepatan penurunan tanah dan menghemat biaya jika dibandingkan dengan penambahan tanah urugan (Departemen Pekerjaan Umum, 2005). Perbaikan kekuatan tanah sebaiknya didahului dengan pengerukan hingga $1 \mathrm{~m}$ untuk menghilangkan tanah penutup di permukaan, lalu cerucuk kayu ditusukkan di bawahnya.

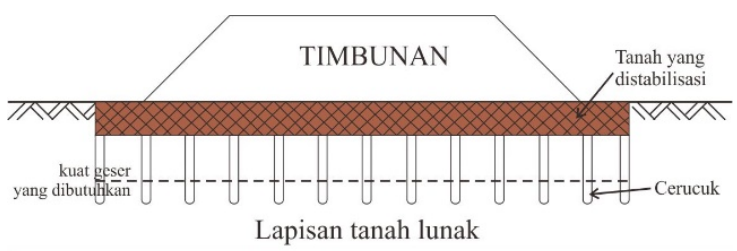

Gambar 7. Contoh instalasi cerucuk pada tanah.

\section{KESIMPULAN}

Tanah di lokasi penelitian pada kawasan Handil Berkat Makmur termasuk jenis gambut berlempung kelanauan dengan konsistensi lunak - sangat lunak, dan kelembaban lembab basah. Fragmen-fragmen tumbuhan juga dijumpai pada tanah sehingga juga dikategorikan sebagai tanah organik.

Nilai daya dukung tanah yang dimiliki oleh tanah di lokasi penelitian termasuk rendah karena berada di bawah batas nilai rata-rata qult $=440$ ton $/ \mathrm{m}^{2}$ dan qa $=146 \mathrm{ton} / \mathrm{m}^{2}$ yang ditetapkan dalam Panduan Departemen Pekerjaan Umum Tahun 2005. Asumsi beban rumah yang akan dibangun sama dengan beban yang mampu ditahan oleh daya dukung tanah di lokasi penelitian, sehingga sangat dibutuhkan pondasi yang tepat dan rekayasa teknik untuk menambah daya dukung. Pondasi yang direkomendasikan adalah pondasi segiempat dengan cerucuk sebagai tambahan.

\section{UCAPAN TERIMA KASIH}

Penulis bermaksud menyampaikan terima kasih kepada PT. Paksigurdha Paramarta, terutama Bapak Suciarso, Bapak Eko, dan Bapak Fatir, serta staf atas bantuan yang diberikan.

\section{DAFTAR PUSTAKA}

Badan Informasi Geografis, 1994. Peta Penggunaan Lahan Kabupaten Kapuas. Badan Informasi Geografis: Jakarta.

Bappeda Kabupaten Kapuas, 2013. Rencana Detail Tata Ruang Kawasan Kota Kualakapuas. Bappeda Kabupaten Kapuas: Palangkaraya.

Chairullah, B., 2013. Analisa Daya Dukung Pondasi dengan Metoda SPT, CPT, dan Meyerhof pada Lokasi Rencana Konstruksi PLTU Nagan Raya Provinsi Aceh. Teras Jurnal, Vol. 3 No. 1.

Das, B. M., 1995. Mekanika Tanah Jilid II. Erlangga: Jakarta.

Departemen Pekerjaan Umum, 2005. Pedoman Analisis Daya Dukung Pondasi Dangkal. Bada Litbang PU Departemen Pekerjaan Umum No: Pd T-02-2005-A.

Fahriani, F. dan Apritanti, Y., 2015. Analisis Daya Dukung Tanah dan Penurunan Pondasi pada Daerah Pesisir Pantai Utara Kabupaten Bangka. Jurnal Fropil, Vol. 3 No. 2.

Heryanto, R. dan Sanyoto, P., 1994. Peta Geologi Amuntai, Kalimantan. Pusat Penelitian dan Pengembangan Geologi: Bandung.

Roberston, P. K., Campanella, R. G., Gillespie, D., dan Greig, J., 1986. Use of Piezometer Cone data. In-situ Testing in Geotechnical Engineering, ASCE Specialty Conference, hal 1263-1280.

Sikumbang, N. dan Heryanto, R., 1994. Peta Geologi Lembar Banjarmasin, Kalimantan. Pusat Penelitian dan Pengembangan Geologi: Bandung.

Sugiyanto, 2003. Tinjauan Aspek Geologi Teknik untuk Menunjang Rencana Pembangunan Pelabuhan Tanjung Api-Api, Sumatera Selatan. Buletin Geologi Tata Lingkungan, Vol. 13 No. 2.

Terzaghi, K. dan Peck, R. B., 1948. Soil Mechanics in Engineering Practice, $1^{\text {st }}$ Edition. John Wiley and Sons: New York.

Utami, T. E. dan Hermawan, 2003. Perbandingan Nilai Daya Dukung Pondasi Dangkal Berdasarkan Data Sondir dan Parameter Tanah pada Satuan Lempung Endapan Rawa (Qs) di daerah Kabupaten Musi Banyuasin Bagian Timur, Sumatera Selatan. Jurnal Geologi Tata Lingkungan, Vol. 13 No.2, hal. 110-116.

Verheof, P. N. W., 1994. Geologi untuk Teknik Sipil. Erlangga: Jakarta. 
Virman, 2013. Analisis Data Geolistrik dan Data Uji Tanah untuk Menentukan Struktur Bawah Tanah Daerah Skyland Distrik Abepura Papua. Jurnal Fisika, Vol. 3 No. 1. Wesley, L. D., 2010. Mekanika Tanah untuk Tanah Endapan dan Residu. Penerbit Andi : Yogyakarta. 